\title{
MENGGUNAKAN KONSEP “AT-TURĀं் WA AT-TAJDĪD" DALAM PEMIKIRAN HASSAN HANAFI UNTUK MENGATASI KEMISKINAN DI INDONESIA
}

\author{
Yuli Andriansyah \\ Prodi Ekonomi Islam, FIAI, Universitas Islam Indonesia, Yogyakarta \\ Email: yuliandriansyah@gmail.com
}

\section{Abstract}

Considering that the poverty becomes the critical issue in almost all Muslim countries, it is crucial if the issue and its solution are exposed and discussed. To discuss the poverty and its solution, this article concerns to one of approaches stated by Hasan Hanafi. According to him, the poverty can be solved by increasing the individuals and private companies participations, which is in this case the business world is demanded to be more active in helping and developing the living quality of poor citizens. The role of the individuals and private companies in alleviating the poverty is the significant aspect which helps the government program to tackle the poverty problem. This article also suggests the role of the government to support the individuals and private companies to help the poor citizens. The incentive can be given to individuals or the companies which actively involve in the poverty alleviation program. The implementation of Hasan Hanafi's idea about at-turāts wa at-tajdìd is proven to be effectively applied even though it has many challenges.

\section{تجريد}

نظرا إلى مشكلة الفقر الحادة في معظم الدول الإسلامية تقريبا، فإنه من المعقول إذا كان الحديث عن هذه المشكلة والحلول المقترحة فيها من الأمور الجحديرة بالنقاث. ومن أجل البحث في الفقر والجهود المبذولة للتغلب عليها، فهذه المقالة تشير الى أحد آراء حسن حنفي، حيث قال إنه يهل بترقية مشاركة الأفراد والقطاع الخاص في بحال الأعمال لمساعدة حياة الناس الفقراء وتحسين حياهم. إن الأفراد 


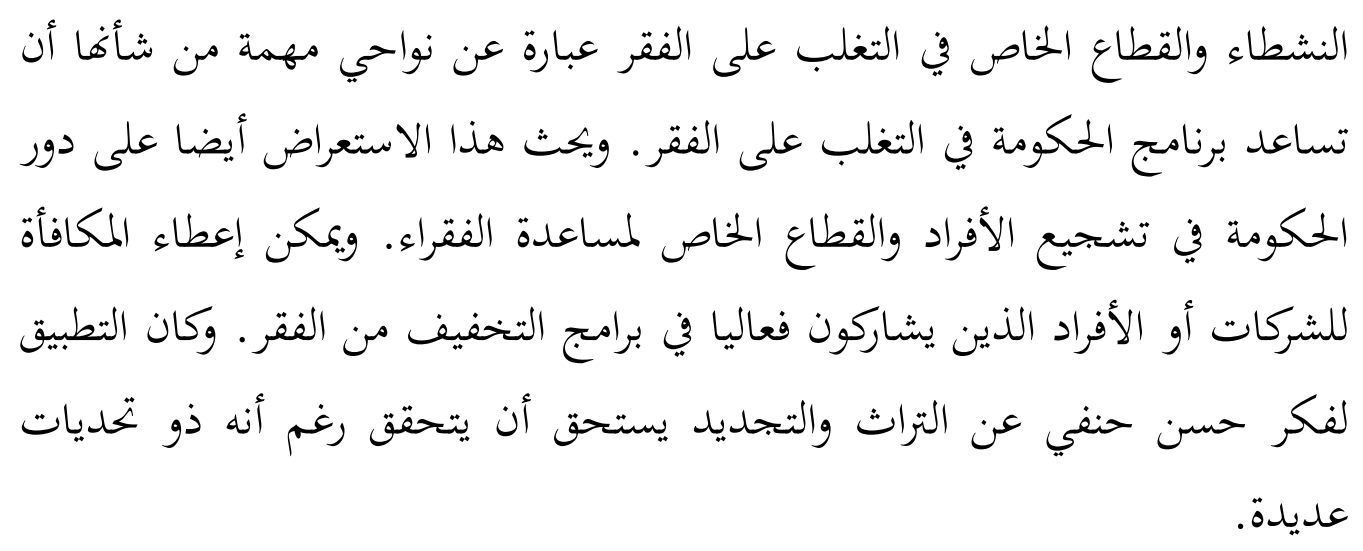

Keywords: Kemiskinan, Indonesia, Pemikiran, Hassan Hanafi

\section{A. Pendahuluan}

Kemiskinan hingga saat ini masih menjadi masalah krusial di Indonesia. Konstitusi Indonesia yaitu UUD 1945 secara tegas menyebutkan bahwa "kesejahteraan seluruh rakyat Indonesia" adalah salah satu tujuan nasional yang hendak dicapai dalam kehidupan bernegara. Di masa penjajahan, dimana kekuasaan berada di tangan kolonial, impian menjadi bangsa yang sejahtera memang sulit diwujudkan. Oleh karenanya kemerdekaan menjadi sebuah harapan akan munculnya pemerintahan yang mampu mewujudkan cita-cita mulia tersebut. Namun demikian, seiring perjalanan waktu, cita-cita menjadi bangsa yang sejahtera tersebut nampaknya masih jauh dari harapan. Pergantian kekuasaan selama ini belum mampu menjamin tercapainya kesejahteraan rakyat secara menyeluruh.

Bagi umat Islam di Indonesia, yang menjadi bagian terbesar penduduk, kemiskinan juga menjadi momok menakutkan mengingat implikasi sosialnya. Kemiskinan pada umat Islam sebagaimana disinyalir dalam sebuah hadits Nabi Muhammad Saw berpotensi membawa kepada kekufuran. Selain itu, fakta bahwa umat Islam masih banyak hidup di bawah garis kemiskinan juga mengisyaratkan adanya permasalahan serius dalam aspek kepedulian sosial. Islam mengajarkan umatnya untuk saling bekerjasama dalam kebaikan termasuk dengan membantu sesamanya yang membutuhkan. Dengan demikian keberadaan sekelompok besar masyarakat miskin dalam umat Islam 
di bumi yang sangat kaya sumber daya ditambah dengan banyaknya orang kaya merupakan sebuah fenomena yang layak menjadi perhatian.

Kemiskinan yang melanda umat Islam Indonesia pada dasarnya juga dialami umat Islam di banyak negara, termasuk negara dengan penduduk muslim sebagai mayoritas. Hal ini antara lain dapat dilihat dari kecenderungan negara-negara Islam yang masih masuk kategori negara berkembang (developing countries) bahkan terbelakang (underdeveloped countries). Jika pun terdapat negara Islam dengan status negara maju (developed countries), maka kekayaan alamlah yang seringkali menjadi pendorong kemajuan tersebut. Atas dasar ini, maka dapat disimpulkan bahwa kemajuan kehidupan umat Islam saat ini masih jauh dari ideal jika dibandingkan dengan capaian umat Islam di masa lalu.

Mengingat kemiskinan menjadi masalah yang akut di hampir semua negara berpenduduk muslim, maka wajar kiranya jika pembahasan mengenai hal tersebut beserta cara mengatasinya dikemukakan dan didiskusikan. Untuk membahas kemiskinan dan upaya mengatasinya, artikel ini akan mengacu pada salah satu pandangan yang dikemukakan oleh Hassan Hanafi, seorang pemikir Islam kontemporer dari Mesir, yaitu tentang At-Turäs wa At-Tajdìd atau tradisi dan pembaharuan. Hassan Hanafi dipilih mengingat kapasitas akademik dan popularitasnya beserta pemikirannya di dunia Islam termasuk Indonesia.

Untuk membahas bagaimana at-turāis wa at-tajdìd akan digunakan untuk merumuskan upaya pengentasan kemiskinan makalah ini akan menggunakan struktur pembahasan sebagai berikut: bagian pertama berisi latar belakang yang menjelaskan konteks dan kerangka kajian dalam artikel ini, bagian kedua berisi paparan singkat mengenai pribadi dan karakter Hassan Hanafi sebagai seorang pemikir Islam kontemporer, bagian ketiga menjelaskan pemikiran Hassan Hanafi tentang at-turās wa at-tajdìd sebagai salah satu kontribusinya untuk membangkitkan kembali kejayaan umat dengan memperhatikan khazanah pemikiran di masa lalu untuk perbaikan hari ini, bagian keempat akan menguraikan bagaimana konsep at-turās wa at-tajdìd yang dirumuskan Hassan Hanafi dioperasionalkan dalam upaya mengatasi kemiskinan di Indonesia, sekaligus mendiskusikan dan membahas hasil kajiannya, dan bagian kelima akan menyimpulkan kajian akhir sekaligus menyajikan saran pengembangan. 


\section{B. Sekilas Mengenai Hassan Hanafi}

Hasan Hanafi dilahirkan di Kairo pada 1935 dari sebuah keluarga yang memiliki kegandrungan pada seni. Hassan Hanafi sendiri juga darah seni tersebut terbukti dari kemampuannya bermain biola sejak kecil hingga kini. ${ }^{1}$ Pendidikan dasar diselesaikan oleh Hassan Hanafi pada 1948. Ia kemudian melanjutkan pendidikan di Madrasah Tsanawiyah Khalil Agha, Kairo dan selesai pada 1952. Hassan Hanafi mulai aktif mengikuti diskusi-diskusi dan menjadi anggota Ikhwanul Muslimin, yang kala itu merupakan salah satu organisasi masa paling populer di masa revolusi politik di Mesir. ${ }^{2}$ Pemikiran Hassan Hanafi pun berkembang melalui sejumlah kegiatan tersebut. Ia juga memiliki kesempatan untuk mempelajari pemikiran Sayyid Qutb, sebagai salah seorang ideolog utama Ikhwanul Muslimin, tentang Islam dan keadilan sosial. $^{3}$

Hassan Hanafi kemudian melanjutkan studi di Universitas Kairo pada bidang filsafat hingga meraih gelar sarjana pada 1956. Ia kemudian menempuh pendidikan di Universitas Sorbonne, Prancis, dengan konsentrasi kajian pemikiran Barat pra-modern dan modern. Ia menyelesaikan program master dan doktornya pada 1966, dengan tesis berjudul Les Methodes d'Exegeses: Essei sur La Science des Fondament de La Conprehension Ilmu Ushul Figh dan desertasi berjudul L'Exegese de La Phenomenologie, L'etat actuel de la Methode Phenomenologie et son application au Phenomene Religiux. ${ }^{4}$

Hassan Hanafi kemudian memulai karir akademiknya pada 1967 dan pada 1980 ia menjabat guru besar filsafat di Universitas Kairo. Ia juga sempat menjadi akademisi tamu (visiting scholars) di sejumlah negara seperti Prancis, Belgia, Amerika Serikat, Kuwait, Maroko dan Jepang. Ia juga diangkat sebagai guru besar tamu di Universitas Tokyo1984-1985, dan menjabat penasihat program

1 Wikipedia, "Hassan Hanafi", Artikel website diakses dari http://en.wikipedia.org/ wiki/Hassan_Hanafi pada 1 Maret 2011.

2 InpasOnline.com, "Kritik Terhadap Metodologi Tafsir Al-Qur'an Hasan Hanafi", 30 September 2010, Artikel website diakses dari http://inpasonline.com/new/kritik-terhadapmetodologi-tafsir-al-quran-hasan-hanafi/ 1 Maret 2011 dan Wikipedia, "Hassan Hanafi".

3 Ibid.

4 Ahmad Khudori Sholeh, Pemikiran Islam Kontemporer, Hasan Hanafi: Hermeneutika Humanistik (Yogyakarta: Jendela. 2003), hal. 157 dikutip dalam InpasOnline.com, "Kritik Terhadap Metodologi Tafsir Al-Qur'an Hasan Hanafi". 
di Universitas PBB di Jepang pada 1985-1987. ${ }^{5}$ Ia juga aktif dalam beberapa organisasi ilmiah dan kemasyarakatan yang berafiliasi pada negaranya Mesir maupun Afrika dan juga Arab. ${ }^{6}$

Paparan mengenai latar belakang Hassan Hanafi di atas menunjukkan bagaimana konteks kehidupan awalnya dan pengaruhnya hingga ia memunculkan pemikirannya. Ia lahir dari keluarga yang relatif hidup cukup sejahtera dibandingkan lingkungan sekitarnya. Namun pada saat yang sama ia hidup di masa revolusi sebagai upaya negara-negara Islam termasuk Mesir dan negara Arab lainnya membebaskan diri dari belenggu penjajahan. Selepas dari penjajahan, sebagaimana negara baru, Mesir pun dilanda konflik politik terutama perebutan kekuasaan yang melibatkan anasir-anasir agama sosial dan kemasyarakatan. Sebagai negara yang pernah dijajah Prancis, Mesir yang pada dasarnya telah memiliki warisan intelektual juga mengadopsi sejumlah pola hukum Prancis yang terinspirasi Revolusi Prancis. Revolusi ini dan pemikiran di belakangnya memang menghendaki adanya kebebasan, persamaan dan persaudaraan sesama manusia.

Semangatrevolusitersebutjugaikutmempengaruhi HassanHanafiterutama ditambah dengan khazanah pemikiran Islam semisal pandangan-pandangan revolusioner Sayyid Quthb maupun Usman Amin. Posisi intelektual Hassan Hanafi semakin matang berkat studinya di Universitas Sorbonne Prancis yang merupakan salah satu pusat akademik terbaik dunia. Sebagai seorang sarjana baru dari sebuah negara yang baru menapak jalan menuju kemerdekaan, Hassan Hanafi kemudian beranjak menuju kematangan akademik di negara kolonialis yang telah menikmati beragam hasil pembangunan. Realitas yang sedemikian timpang sewajarnya memunculkan semangat perubahan dalam diri Hassan Hanafi untuk melahirkan peradaban baru di kampung halamannya yang mampu mengejar sejumlah ketertinggalan dibandingkan negara maju.

Mengingat konsentrasi kajiannya di bidang filsafat terutama filsafat hukum yang dalam Islam masuk dalam kajian Ushul Fiqh, maka tidak mengherankan jika Hassan Hanafi memulai usaha revolusionernya dari kajian ini. Inilah alasan mengapa kajian dan teori yang diajukan Hassan Hanafi untuk membangun

5 InpasOnline.com, “Kritik Terhadap Metodologi Tafsir Al-Qur'an Hasan Hanafi” dan Wikipedia, "Hassan Hanafi".

6 InpasOnline.com, "Kritik Terhadap Metodologi Tafsir Al-Qur'an Hasan Hanafi” 
masyarakat Islam berawal dari fondasi dasar dalam Islam itu sendiri, seperti bahasa, filsafat hukum Islam, budaya, dan terutama penafsiran terhadap kitab suci. Perlu juha digarisbawahi bahwa penjajahan Prancis atas sejumlah negara di Afrika Utara memungkinkan akses terhadap bahasa Prancis selain bahasa Arab bagi para intelektual di wilayah tersebut. Hassan Hanafi tentu saja memiliki keuntungan tersebut sehingga akses dan pemahaman terhadap sejumlah pemikir Prancis maupun Eropa dapat diperolehnya.

\section{Pemikiran Hassan Hanafi tentang At-Turāts wa At-Tajdìd}

Sebagaimana telah diulas sebelumnya, pemikiran mengenai pembaharuan Hassan Hanafi merupakan konsekuensi logis dari perkembangan akademiknya dalam dua lingkungan sosial politik yang berbeda, yaitu Mesir yang mewakili keterbelakangan dan Prancisyang mewakili kemajuan. Dari landasanini,Hassan Hanafi kemudian memunculkan pemikiran untuk melakukan revolusi dengan pendekatan Ushul Fiqh dan sumber ajaran Islam sebagai senjatanya. Pemikiran yang dikaji dalam makalah ini dibatasi pada pemikiran tentang at-turāts wa attajdìd. Pemikiran Hassan Hanafi tentang at-turāts wa at-tajdìd mengacu pada tiga kerangka yang saling terhubung yaitu: a) merekonstruksi tradisi Islam dengan interpretasi secara kritis dan melakukan kritik historis yang diwujudkan dalam bentuk pengakuan terhadap khazanah klasik (mawqifunā min al-qadīm); b) merekonstruksi ulang sekat-sekat budaya Barat dengan mengkaji secara kritis sehingga mewujudkan sikap terhadap Barat (mawqifunā min al-gharb); dan c) membangun sebuah tafsir pembebasan Alquran dengan cakupan beragam kebudayaan dunia dimana Islam menjadi fondasi bagi kemanusiaan sehingga terwujud sikap terhadap realitas (mawqifunā min al-wāqū). ${ }^{7}$

Ketiga hal ini yang menjadi fondasi pemikiran Hassan Hanafi ini muncul mengingat manusia di mana pun tidak dapat dipisahkan dari tiga hal sekaligus, yaitu masa lalu (al-māḍ̂̀), masa depan (al-mustaqbal), dan masa kini (al-hầlì). Masa lalu bagi umat Islam menurut Hassan Hanafi tercermin pada kekayaan khazanah Islam sebagai bagian dari peradaban yang sebelumnya telah mampu mencapai puncak kejayaan. Masa lalu ini selanjutnya terekam dengan baik dalam tradisi klasik atau at-turāts al-qadìm. Sedangkan masa depan yang ingin

7 InpasOnline.com, “Kritik Terhadap Metodologi Tafsir Al-Qur'an Hasan Hanafi”. 
dicapai adalah kemajuan sebagaimana dicapai oleh peradaban Barat modern saat ini dengan berbagai teknologi dan kemajuan lainnya. Masa depan ideal ini kemudian tertuang dalam khazanah barat atau at-turāts al-gharb. Sedangkan masa kini terwujud dalam kondisi umat Islam di berbagai belahan dunia, termasuk negaranya sendiri yaitu Mesir, yang cenderung terbelakang miskin dan tidak mampu menghadapi kemajuan negara maju. Realitas kontemporer atau al-wāqi inilah wajah daripada kondiri umat Islam terkini yang ingin dirubah melalui gerakan at-turāts wa at-tajdìd Hassan Hanafi. ${ }^{8}$

Untuk mencapai kondisi ideal di atas, salah satu jalan utama yang dapat digunakan menurut Hassan Hanafi adalah melalui tafsir terhadap Alquran sebagai kitab suci yang paripurna sesuai dengan perkembangan peradaban manusia. Namun demikian, Hassan Hanafi merasa penafsiran Alquran selama ini masih memiliki sejumlah kekurangan, sehingga ia mengajukan sejumlah karakteristik baru dalam tafsir. Menurut Hassan Hanafi, penafsiran yang baik hendaknya memenuhi sejumlah karakteristik, yaitu : a) harus menghasilkan tafsir yang bersifat spesifik (at-tafsir al-juz'i); b) juga harus bersifat tafsir tematik (at-tafsir al-maudhu'i); c) sifat tafsir adalah temporal (at-tafsir az-zamani) atau memiliki batasan waktu terutama relevansinya; d) tafsir bersifat realistik (attafsir al-waqi'i) atau sejalan dengan kondisi kekinian; e) berorientasi pada tujuan, makna dan kepentingan tertentu bukan semata teori tentang kata dan huruf; f) tafsir bersifat experimental yaitu sesuai dengan kehidupan dan pengalaman hidup mufassir; dan g) tafsir hendaknya memperhatikan problem kontemporer yang dihadapi umat.

Berdasarkan penjelasan di atas, maka tafsir menjadi salah satu celah penting dalam membangun peradaban berdasarkan kerangka at-turāts wa attajdid Hassan Hanafi. Hal ini dapat dipahami dari logika sederhana mengenai posisi tafsir dalam kaitannya dengan pemahaman terhadap kitab suci. Tafsir dapat diartikan sebagai terjemahan yang dapat dengan mudah dipahami oleh pembaca sebuah kitab suci. Bahkan jika pun sebuah kitab suci turun dalam bahasa ibu seseorang, ia tetap akan memperoleh banyak manfaat dari membaca kitab tafsir karena pengetahuannya akan kitab suci akan makin bertambah.

8 Muhammad Abu Nadlir, "Legasi dan Pembaharuan Hasan Hanafi", 20 Oktober 2010, Artikel website diakses dari http://abuenadlir.blogspot.com/2010/10/legasi-danpembaharuan-hasan-hanafi.html 1 Maret 2011. 
Dalam konteks Indonesia, kitab tafsir menjadi kebutuhan mutlak mengingat bahasa Alquran adalah dalam bahasa Arab dan terjemahan Alquran jelas tidak mencukupi untuk memahami makna Alquran secara menyeluruh. Oleh karenanya, makalah ini akan menggunakan kitab tafsir yang ada di kalangan umat Islam Indonesia terutama yang dikarang oleh penduduk asli untuk menangkap semangat pembebasan yang ada pada diri penafsir sesuai dengan konteks kehidupannya.

\section{Pemikiran Hassan Hanafi untuk Mengatasi Kemiskinan di Indonesia}

1. Modifikasi Pemikiran Hassan Hanafi tentang At-Turāts wa At-Tajdìd untuk Mengatasi Kemiskinan

Sebagaimana disinggung di atas, konsep at-turāts wa at-tajdìd yang ditawarkan oleh Hassan Hanafi pada dasarnya mengakui adanya khazanah klasik dalam sebuah masyarakat sekaligus mengakui adanya khazanah dari peradaban yang lebih maju dan sukses yaitu peradaban barat. Di sisi lain terdapat kondisi umat Islam yang dalam situasi serba sulit karena tertinggal di berbagai aspek kehidupan yang perlu diperbaiki dan diangkat derajatnya. Kondisi ideal yang dicapai Barat saat ini, merupakan salah satu yang ingin juga dicapai oleh Hassan Hanafi melalui at-turāts wa at-tajdìd. Pada saat yang sama, Hassan Hanafi mengakui dan mengharapkan nilai-nilai Islam sebagaimana terpendam dalam Alquran mampu menjadi warna dominan dalam peradaban modern, sembari tetap mengakui adanya peradaban lain.

Dengan memahami konsep di atas, maka kondisi kemiskinan di Indonesia akan dapat dianalisis untuk kemudian sejumlah kerangka kebijakan dapat dirumuskan dan dimunculkan. Khazanah Islam klasik atau at-turāts al-qadìm dalam konteks Indonesia dapat kita lihat dalam kitab-kitab tafsir atau buku-buku tentang Alquran yang di dalamnya dikaji berbagai permasalahan termasuk kemiskinan. Sedangkan at-turāts al-gharb atau khazanah Barat yang lebih maju dapat diwakili capaian sejumlah negara maju atau minimal sejumlah negara tetangga yang lebih sukses secara ekonomi: Malaysia, Thailand, dan Singapura. Pemikiran Hassan Hanafi dalam kerangka at-turāts wa at-tajdìd diharapkan dapat mengatasi kondisi kemiskinan yang saat ini dialami bangsa Indonesia sebagai al-wāqi . 
Kitab-kitab tafsir atau buku-buku tentang Alquran yang masuk dalam at-turāts al-qadìm dapat ditemukan dalam beragam karya ulama dan pemikir Indonesia atau dalam kitab-kita yang dapat disebut sebagai tafsir nusantara. Adapun tafsir nusantara yang dimaksud mencakup setidaknya Marāh Labìd li KasyfMa'nāal-Qur'ān al-Majìd, Tafsir Al Qur'anul Majid An Nur, Tafsir Al-Azhar, Al Qur'ān dan Tafsirnya, dan Tafsir Al-Mishbäh. Keseluruhan tafsir ini menggunakan tartib mushhafi dalam artian pembahasan ayat per ayat di dalamnya mengacu urutan sebagaimana terdapat dalam mushaf 'Utsmanī atau Alquran standar yang ada di antara kita. Selain Marāh Labìd li Kasyf Ma'nā al-Qur'ān al-Majìd yang menggunakan bahasa Arab, tafsirtafsir ini menggunakan Bahasa Indonesia atau rumpun terdekatnya yaitu Bahasa Melayu.

Tafsir-tafsir ini dan juga tafsir lainnya disebut tafsir nusantara dan bukan tafsir Indonesia mengingat beberapa alasan. Pertama, misalnya dalam kasus tafsir Marāh Labìd li Kasyf Mánā al-Qur'ān al-Majīd, kitab tafsir berbahasa Arab ini disusun oleh Nawawî Al-Bantanî yang semasa hidupnya Indonesia seperti yang kita kenal saat ini belumlah ada. Sehingga selain menggunakan gelar (laqab) asal daerahnya yaitu Banten, beliau juga menggunakan gelar al-Jâwî yang pada masa tersebut meliputi wilayah Indonesia saat ini, Malaysia, Singapura, Brunei Darussalam, Filipina Selatan, dan Thailand Selatan. Kedua, penggunaan Bahasa Melayu yang terutama sangat kuat terlihat pada Tafsir An-Nur dan Tafsir Al-Azhar memungkingkan pengguna tafsir ini menyebar di wilayah-wilayah yang disebutkan sebelumnya. Bahkan salah satu tafsir ini diterbitkan di Singapura oleh penerbit setempat, meskipun tidak pernah meminta izin dari penerbit di Indonesia. Ketiga, kitab-kitab tafsir yang digunakan juga diacu dan dikaji dalam berbagai lembaga pendidikan di wilayah-wilayah yang telah disebutkan. Dengan demikian tafsir-tafsir ini memiliki cakupan yang seluas wilayah nusantara di masa lalu.

Namun demikian, mengingat keterbatasan pada pembahasan ini, tafsir yang akan digunakan hanyalah Marāh Labìd li KasyfMa'nā al-Qur'ān al-Majīd (selanjutnya disebut Marāh Labìd). Tafsir ini disusun oleh Abū 'Abd al-Mu'thī Muhammad Nawawī bin 'Umar bin 'Arabī bin 'Alī al-Jāwī al-Bantānī alTanarī al-Syāfi' ī al-Qādirī (selanjutnya disebut Nawawī Al-Bantanī). Beliau 
lahir di Kampung Tanara, Serang, Banten pada tahun 1815 M/1230 H dan wafat serta dimakamkan di Mekkah pada 25 Syawal 1314 H/1897 M. Nama tafsirnya kemudian berubah menjadi al-Tafsìr al-Munìr li Ma'ālim al-Tanzì dan berubah lagi menjadi Tafsìr al-Nawawì pada cetakan ulang di Arab Saudi. ${ }^{9}$ Secara umum, Nawawī Al-Bantanī dalam tafsirnya menggunakan metode tahlìi dengan pendekatan tafsìr bi al-ma'tsūr (tafsir dengan sumber riwayat) dan tafsìr bi al-ra'y (tafsir dengan sumber pemikiran) sebagaimana kebanyakan kitab tafsir yang ditulis berdasarkan tata urutan ayat dan surah al-Qur'ân. Dalam kitab Marâh Labîd ini, hadits Nabi saw menempati posisi penting dalam menafsirkan ayat-ayat al-Qur'ân sehingga perpaduan antara tafsìr al-āyah bi al-âyah (tafsir ayat dengan ayat) dan tafsìr al-āyah bi al-sunnah (tafsir ayat dengan hadits) sangat dominan. ${ }^{10}$

Dengan demikian, pembahasan mengenai bagaimana khazanah Islam klasik Indonesia digunakan untuk merumuskan kebijakan pengentasan kemiskinan akan dipusatkan pada makna kemiskinan dalam kitab Marāh Labid. Adapun penentuan mengenai ayat-ayat mana saja yang akan dibahas mengacu pada sejumlah buku terkait Alquran, terutama glosari dan sejenisnya yang ada di Indonesia. Penelusuran ayat-ayat mengenai kemiskinan dan penjelasannya dalam kitab Marāh Labìd akan disajikan dalam bagian berikut.

2. Kemiskinan dalam Buku-buku Kajian Alquran dan Tafsir Marāh Labìd

Sebagaimana disebutkan sebelumnya, bagian ini akan mengkaji bagaimana kemiskinan dianalisis di berbagai buku tentang Alquran untuk kemudian dianalisis melalui kitab Marāh Labìd. Kemiskinan menjadi topik utama yang banyak dikaji dalam bidang tafsir maupun studi Alquran pada sejumlah kitab dan buku yang terbit di Indonesia. Kajian tentang kemiskinan disajikan baik dalam kaitannya dengan visi ekonomi Alquran tentang kesejahteraan maupun pemerataannya.

Syahminan Zaini menyebutkan bahwa dalam Alqur'an ekonomi dimaksudkan untuk mencapai kemakmuran dalam hidup sehingga menjadi kewajiban bagi manusia untuk mewujudkannya berdasarkan Q.S.

9 Mustamin Arsyad, "Signifikansi Tafsir Marāh Labīd terhadap Perkembangan Studi Tafsir di Nusantara", Jurnal Studi al-Qur'ān, Vol. 1 (3) 2006, hal. 615-636.

10 Ibid. 
Hud ayat 61. Kemakmuran yang diciptakan dari aktivitas ekonomi yaitu produksi, distribusi dan konsumsi, diharapkan dapat dinikmati secara merata oleh semua orang. Atas dasar itu, Alquran memuji mereka yang gemar berbuat baik kepada kelompok masyarakat yang membutuhkan seperti kerabat, anak yatim, orang miskin, orang meminta-minta dan juga memerdekakan hamba sahaya sebagaimana tercermin dalam Q.S. AlBaqarah ayat 117. Alquran bahkan mengancam dengan sebutan pendusta agama bagi mereka yang enggan membantu kelompok masyarakat yang membutuhkan tersebut sebagaimana tersurat dalam Q.S. Al-Maun ayat 1-3. Komitmen membantu masyarakat yang membutuhkan juga diperkuat dengan penegasan adanya hak orang-orang faqir, miskin, dan sebagainya di dalam harta orang kaya sebagaimana dijelaskan dalam Al-Isra ayat 26, Adz-Dzariyat ayat 19 dan At-Taubah ayat $60 .{ }^{11}$

Afzalur Rahman menyebutkan bahwa Alquran mengakui adanya ketidakmerataan ekonomi dalam masyarakat, sebagaimana diisyaratkan dalam Q.S. [6] ayat 165 dan Q.S. [43] ayat 32. ${ }^{12}$ Ia juga menegaskan bahwa masyarakat Islam memiliki tanggung jawab untuk mencukupi kebutuhan kelompok masyarakat yang hidup miskin dan fakir. Bahkan sekiranya negara tidak mencukupi dana untuk memenuhi kebutuhan tersebut, dapat diberlakukan aturan hukum yang memungut pajak dari orang kaya untuk digunakan bagi upaya memenuhi kebutuhan dasar masyarakat miskin tersebut. Hal ini penting untuk dilakukan agar umat Islam tidak mendapat hukuman di akhirat sebagai akibat dari kelalaian terhadap hak orang miskin tersebut. Dalam konteks ini menurutnya Q.S. Al-Maun [107] ayat 1-3 sangat relevan. ${ }^{13}$

Menurut Rachmat Taufiq Hidayat, kata masākīn yang artinya orangorang miskin, terulang dalam sejumlah tempat dalam Alqur'an yaitu [2] ayat $83,177,215,[4]$ ayat $36,[5]$ ayat $95,[8]$ ayat 41, [24] ayat 22, dan [59] ayat 7 . Sedangkan untuk kata miskīn yang makna asalnya adalah diam atau orang yang patut dikasihani, dapat ditemukan dalam sejumlah tempat

11 Syahminan Zaini, Isi Pokok Ajaran Al-Qur'an, (Jakarta: Kalam Mulia, 1986), hal. 145146.

12 Afzalur Rahman, Al Qur'an Sumber Ilmu Pengetahuan, diterjemahkan oleh M. Arifin dari Quranic Scince, (Jakarta: Bina Aksara, 1989), hal. 202.

13 Ibid., hal. 208. 
dalam Alqur'an yaitu [2] ayat 184, [17] ayat 26, [30] ayat 38, [58] ayat 4, [76] ayat 8 , dan [107] ayat 3 . Lebih lanjut ia menyebutkan bahwa miskin tidak jauh berbeda dengan faqīr, yaitu sama-sama membutuhkan, hanya saja orang miskīn tidak malu untuk meminta-minta sedangkan orang faqīr menjaga iffah-nya dengan tidak meminta. ${ }^{14}$

M.S. Khalil menyebutkan kata miskin dalam Alquran diderivasi dalam beberapa bentuk. Kata 'miskin' yang dikaitkan dengan miskin sebagai ujian dapat ditemukan dalam Q.S. [89] ayat 15-17 dan larangan membunuh anak karena miskin ada pada Q.S. [6] ayat 151 dan Q.S. [17] ayat 31. Sedangkan untuk kata 'orang miskin', terdapat sejumlah turunan, yaitu memberi makan orang miskin pada Q.S. [90] ayat 16, menyediakan harta untuk orang miskin dalam Q.S. [17] ayat 26-30 dan Q.S. [30] ayat 38, enggan mendorong memberi makan orang miskin ditemukan dalam Q.S. [69] ayat 34, [89] ayat 18, dan [107] ayat 3 , serta perintah berbuat baik kepada orang miskin pada [4] ayat $36 .{ }^{15}$

Ahsin W. Al-Hafidz menyebutkan bahwa orang miskin adalah yang tidak mampu mencukupi kebutuhan hidup pribadi, keluarga dan tanggungannya meskipun memiliki harta dan pekerjaan. Kelompok orang miskin atau disebut masākīn berhak menerima zakat sehingga terbebas dari kewajiban ibadah berdimensi harta seperti zakat, infaq, sedakah maupun haji. Alquran menyebut kelompok ini dalam sejumlah ayat yaitu Q.S. AlBaqarah [2] ayat 83 dan 215, Q.S. An-Nisa [4] ayat 8, Q.S. At-Taubah [9] ayat 60, Q.S. Al-Isra [17] ayat 17, Q.S. Ar-Rum 38, Q.S. Al-Hasyr ayat 7, Q.S. Al-Qalam ayat 24, Q.S. Al-Hqaqah ayat 34, Q.S. Al-Mudatsir ayat 44, Q.S. Al-Balad ayat 16, dan Q.S. Al-Maun ayat 3. ${ }^{16}$

Jejen Musfah menyebutkan bahwa kata miskin dalam Bahasa Indonesia disebutkan sebanyak lima kali dalam Alquran. Kelima penyebutan tersebut yaitu pada Q.S. Al-Baqarah [2] ayat 83, Q.S. An-Nisa [4] ayat 36, Q.S. AtTaubah [9] ayat 28, Q.S. Al-Isra [17] ayat 26 dan Q.S. Al-An'am [6] ayat $151 .{ }^{17}$

14 Rachmat Taufiq Hidayat, Khazanah Istilah Al-Quran, (Bandung: Mizan, 1989), hal. 84.

15 M.S. Khalil, Kunci (untuk Mencari Ayat) Al-Quran, (Surabaya: Bina Ilmu, 1990), hal. 146.

16 Ahsin W. Al-Hafidz, Kamus Ilmu Alquran, Cetakan Kedua, (Jakarta: Amzah, 2006), hal. 179

17 Jejen Musfah, Indeks Al-Quran Praktis, Cetakan II (Jakarta: Hikmah, 2007), hal. 343. 
Dari berbagai penjelasan di atas, nampak bahwa sebagian besar penulis menyebut bahwa penggunaan kata miskin dan turunannya dalam Alquran antara lain terekam dalam ayat-ayat berikut:

Q.S. Al-Isra ayat 26:

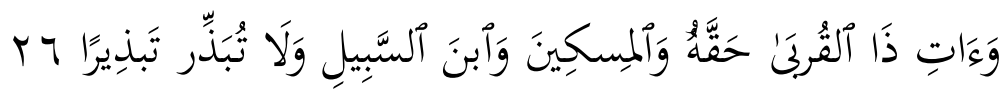

26. Dan berikanlah kepada keluarga-keluarga yang dekat akan haknya, kepada orang miskin dan orang yang dalam perjalanan dan janganlah kamu menghambur-hamburkan (hartamu) secara boros.

Q.S. Adz-Dzariyat ayat 19:

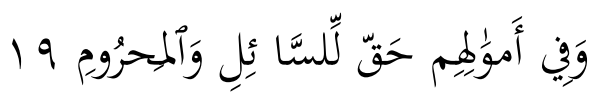

19. Dan pada harta-harta mereka ada hak untuk orang miskin yang meminta dan orang miskin yang tidak mendapat bagian.

Q.S. Taubah ayat 60:

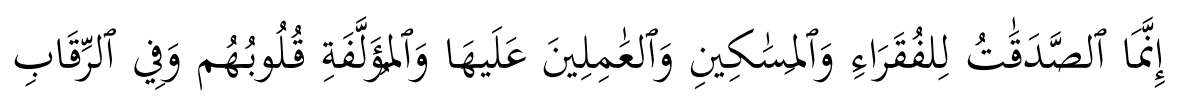

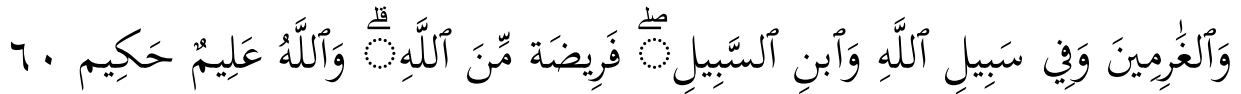

60. Sesungguhnya zakat-zakat itu, hanyalah untuk orang-orang fakir, orangorang miskin, pengurus-pengurus zakat, para mu'allaf yang dibujuk hatinya, untuk (memerdekakan) budak, orang-orang yang berhutang, untuk jalan Allah dan untuk mereka yuang sedang dalam perjalanan, sebagai suatu ketetapan yang diwajibkan Allah, dan Allah Maha Mengetahui lagi Maha Bijaksana.

Q.S. Al-Maun ayat 1-3:

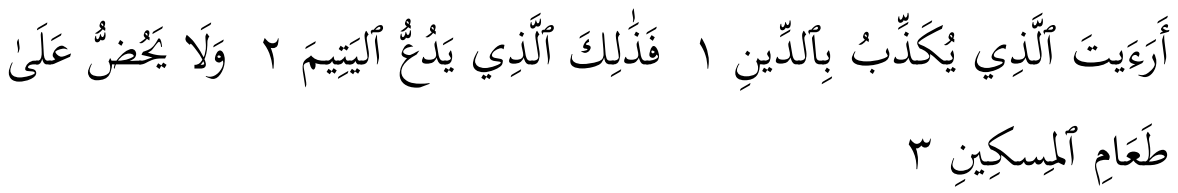

Tahukah kamu (orang) yang mendustakan agama, Itulah orang yang menghardik anak yatim, dan tidak menganjurkan memberi makan orang miskin

Selanjutnya ayat-ayat ini akan dikaji dengan mengacu pada Marāh Labìd. Ayat 26 dari Surat Al-Isra' menurut Nawawī Al-Bantanī bermakna ${ }^{18}$ :

18 Nawawī Al-Bantanī, Marāh Labìd li Kasyf Ma'nā al-Qur'ān al-Majīd, (t.k., Ath-Thaba'ah Al-`Utsmaniyah, 1305 H), Juz 1, hal. 454. 
Berikanlah kepada keluarga dekat baik dari sisi bapak maupun ibu karena merupakan hak mereka untuk menjalin silaturahim dengan harta dan lainya. Berikanlah pula hak orang miskin sebagai perbuatan ihsan kepadanya. Berikanlah kepada tamu yang memasuki rumahmu haknya berupa penghormatan selama tiga malam. Dan janganlah berbuat tabdzir, yaitu menggunakan harta dalam maksiat dan juga dalam berlebihan dalam berhias yang diiringi kesombongan.

Terkait surat Adz-Dzariyat ayat 19, Nawawī Al-Bantanī menjelaskan bahwa sebagian dari sifat orang bertakwa, yang dijelaskan dalam rangkaian ayat-ayat sebelumnya dan setelahnya, terhadap harta adalah: ${ }^{19}$

Mereka hanya mengumpulkan dan menggunakan harta untuk hal yang benar. Mereka memahami bahwa dalam harta mereka terdapat hak orang yang meminta-minta maupun yang kesulitan namun enggan meminta sehingga disangka kaya. Mereka yang tidak meminta ini karena menjaga kehormatannya, namun sebenarnya tetap membutuhkan. Dengan memberikan harta kepada yang meminta maupun tidak, orang-orang yang bertakwa ini telah menyambung tali persaudaraan sekaligus menolong para fakir dan miskin.

Selanjutnya Nawawī Al-Bantanī menjelaskan bahwa makna orang miskin sebagai penerima zakat dalam Surat At-Taubah ayat 60 adalah orang-orang yang berkeliling meminta-minta kepada manusia sebagaimana pendapat yang dinisbatkan kepada Ibnu Abbas. ${ }^{20}$ Sedangkan berkaitan dengan makna "tidak menganjurkan memberi makan orang miskin" dalam ayat 3 Surat Al-Ma'un, Nawawī Al-Bantanī menyebutnya orang yang tidak mendorong keluarganya maupun orang lain yang berkelebihan untuk memberi shadaqah kepada orang-orang miskin. ${ }^{21}$

a. Kemiskinan di Indonesia

Kemiskinan sebagaimana telah disinggung di atas selalu menjadi momok bagi perekonomian dunia, termasuk Indonesia. Dahulu hampir semua penduduk Indonesia hidup miskin (share poverty), sedangkan sekarang kemiskinan terjadi di tengah masyarakat modern dan berkelimpahan (affluent society). Untuk mengukur kemiskinan,

19 Nawawī Al-Bantanī, Marāh Labìd li Kasyf Ma'nā al-Qur'ān al-Majīd, Juz 2, hal. 325.

20 Nawawī Al-Bantanī, Marāh Labìd li Kasyf Ma'nā al-Qur'ān al-Majīd, Juz 1, hal. 328.

${ }^{21}$ Nawawī Al-Bantanī, Marāh Labìd li Kasyf Ma'nā al-Qur'ān al-Majīd, Juz 2, hal. 466. 
terdapat beberapa indikator yang biasa digunakan, yaitu indikator: kemiskinan relatif, kemiskinan absolut, kemiskinan kultural, dan kemiskinan struktural.

Seseorang dikatakan berada dalam kelompok kemiskinan relatif, jika pendapatannya berada di bawah pendapatan di sekitarnya, atau dalam kelompok masyarakat tersebut, ia berada di lapisan paling bawah. Bisa jadi meskipun pendapatannya cukup untuk memenuhi kebutuhan pokok, namun karena dibanding masyarakat di sekitarnya, pendapatannya dinilai rendah, ia termasuk miskin. Amerika Serikat termasuk negara yang menggunakan indikator kemiskinan semacam ini.

Sedangkan dalam konteks absolut kemiskinan dilihat dari kemampuan pendapatan untuk memenuhi kebutuhan pokok (sandang, pangan, pemukiman, pendidikan dan kesehatan). Jika pendapatan seseorang di bawah pendapatan minimal untuk memenuhi kebutuhan pokok, maka ia disebut miskin. Indonesia dan sejumlah negara lainnya menggunakan indikator kemiskinan jenis ini.

Kemiskinan kultural biasanya dikaitkan dengan budaya masyarakat yang "menerima" kemiskinan yang terjadi pada dirinya, bahkan tidak merespons usaha-usaha pihak lain yang membantunya keluar dari kemiskinan tersebut. Sedangkan kemiskinan struktural merupakan kemiskinan yang disebabkan struktur dan sistem ekonomi yang timpang dan tidak berpihak pada si miskin, sehingga memunculkan masalah-masalah struktural ekonomi yang makin meminggirkan peranan orang miskin.

Badan Pusat Statistik (BPS) merupakan lembaga resmi pemerintah yang mengukur garis kemiskinan dengan pendekatan konsumsi sejalan dengan pendekatan Bank Dunia. Garis kemiskinan tersebut diukur dari kemampuan membeli bahan makanan ekuivalen dengan 2100 kalori per kapita per hari dan biaya untuk memperoleh kebutuhan minimal akan barang/jasa, pakaian, perumahan, kesehatan, transportasi, dan pendidikan.

Data kemiskinan di Indonesia biasa dibagi antara kelompok masyarakat di perkotaan dan perdesaan. Selain itu, juga diukur 
presentasenya dengan membandingkan jumlah penduduk miskin dengan total penduduk. Garis kemiskinan yang disusun BPS pada dasarnya senantiasa berubah sesuai dengan perubahan ekonomi. Oleh karenanya, sepanjang waktu garis tersebut mengalami perubahan dengan kecenderungan meningkat meskipun rasio peningkatannya tidak sama antara kota dan desa. Tabel berikut merangkum perkembangan jumlah penduduk miskin, presentasenya dan garis kemiskinan yang digunakan sejak 1970 hingga saat ini di Indonesia. 


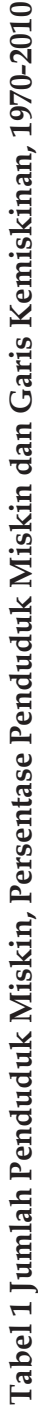

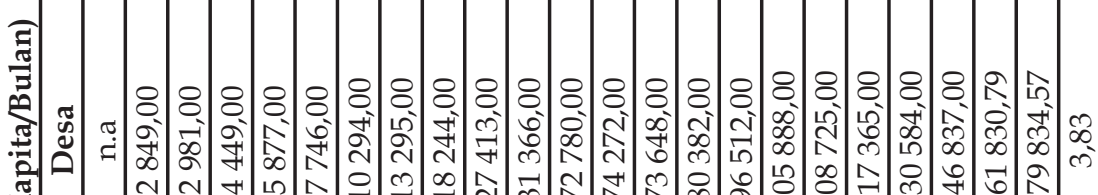
幽 :

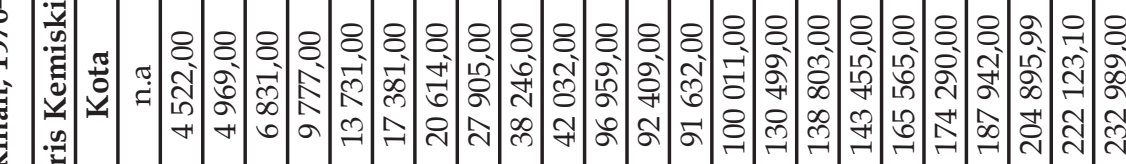

สี

: $\exists$

索

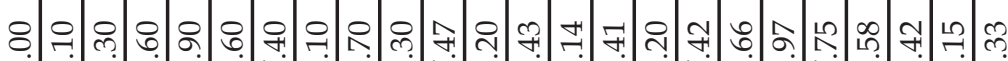
की ले ते तो

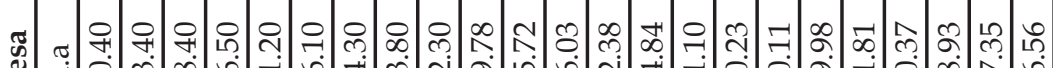
जी

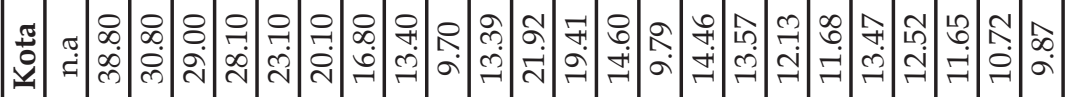

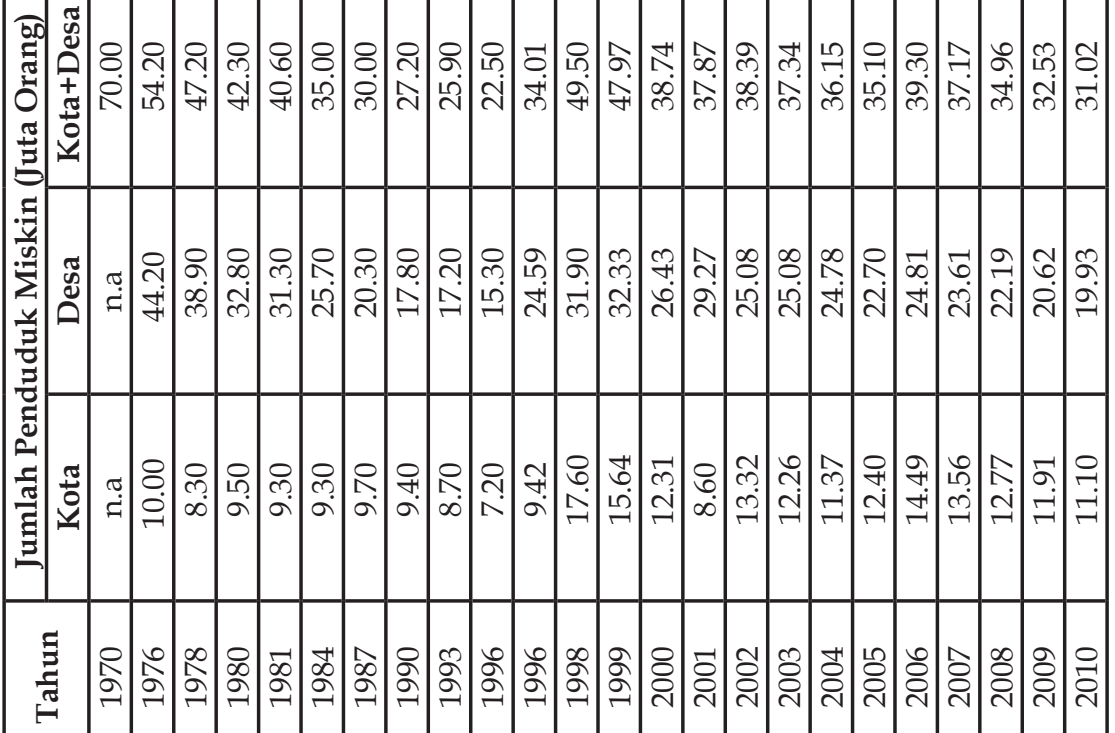


Secara umum tabel di atas menunjukkan bahwa kemiskinan di Indonesia terus mengalami penurunan seiring perbaikan ekonomi. Namun demikian, jumlah penduduk sekitar 31 juta jiwa yang hidup miskin jelas bukan merupakan sesuatu yang layak dibanggakan pemerintah. Sebagai negara dengan penduduk yang besar dan juga memiliki banyak sumber daya alam, kemiskinan yang demikian masif tentu menjadi satu pertanyaan tersendiri. Oleh karenanya, sejumlah peneliti menjelaskan sebab-sebab struktural yang membuat kemiskinan terus ada di Indonesia. Sebab-sebab tersebut antara lain adalah: pertama, ketidakmampuan mengelola sumber daya alam secara maksimal terbukti dari dominannya penguasaan asing atas sumber daya alam strategis di Indonesia; dan kedua, kebijakan ekonomi yang tidak berkomitmen terhadap penanggulangan kemiskinan dan semata-mata mengejar pertumbuhan ekonomi (trickle down effect tidak bekerja).

Kesalahan mendasar dalam asumsi perekonomian Indonesia adalah pengangguran dan kemiskinan hanya mungkin diatasi jika ekonomi tumbuh minimal (misalnya) 6,5 \%. Asusmsi demikian salah, karena yang dapat mengatasi pengangguran dan kemiskinan adalah pertumbuhan ekonomi yang melibatkan kegiatan ekonomi rakyat yang pelakunya adalah masyarakat miskin. Pengangguran dan kemiskinan adalah dua hal berbeda. Orang yang menganggur belum tentu miskin. Sebagai ilustrasi: $1 \%$ pertumbuhan diasumsikan mampu menampung 200.000-400.000 tenaga kerja baru, maka pertumbuhan $6.5 \%$ hanya mampu mempekerjakan 1,3 juta-2,6 juta tenaga kerja dan tidak ada jaminan bagi penduduk miskin yang mencapai puluhan juta jiwa.

Selain itu sejumlah kebijakan atau program penanggulangan kemiskinan selama ini juga memiliki kelemahan seperti: Masih berorientasi pada pertumbuhan ekonomi makro daripada pemerataan; Sentralisasi kebijakan daripada desentralisasi; Lebih bersifat karitatif daripada transformatif; Memposisikan masyarakat sebagai objek dan bukan subjek; Cara pandang tentang penanggulangan kemiskinan masih berorientasi pada 'charity' daripada 'productivity'; dan Asusmsi permasalahan dan solusi kemiskinan sering dipandang sama daripada pluralistis. 
Pemerintahan yang silih berganti di Indonesia, sejak masa kolonial hingga reformasi selalu mengambil kebijakan untuk menanggulangi kemiskinan. Di masa kolonial muncul 'politik etis' atau politik balas budi terhadap bangsa Indonesia sebagai bangsa terjajah. Pada masa inilah mulai dilakukan sejumlah kebijakan termasuk pendidikan, transmigrasi dan sebagainya. Setelah kemerdekaan, konsentrasi masih dipusatkan pada revolusi fisik mempertahankan kemerdekaan sehingga kebijakan pengentasan kemiskinan masih relatif terabaikan.

Pada masa selanjutnya, yaitu masa Orde Baru, sejumlah program pengentasan kemiskinan mulai digulirkan bersamaan dengan program pembangunan nasional sejak Repelita I-V. Terdapat sejumlah program sektoral pada beberapa departemen yang pernah dilaksanakan yang meliputi: BIMAS, INMAS, dan P4K (Departemen Pertanian), UPPKS (BKKBN), KUD dan Koperasi Simpan Pinjam (Departemen Koperasi), UED-SP,BKDdanPKK(DepartemenDalamNegeri),KUBE(Departemen Sosial), Wajar 9 tahun (Departemen Pendidikan dan Kebudayaan) dan pengembangan Puskesmas (Departemen Kesehatan).

Mulai Repelita VI diluncurkan Inpres Desa Tertinggal (IDT), yang meliputi:

a. Komponen bantuan langsung sebesar Rp 20 juta/desa sebagai dana bergulir selama 3 tahun;

b. Bantuan pendampingan pokmas IDT oleh tenaga pendamping Sarjana Pendamping Purna Waktu (SP2W);

c. Bantuan pembangunan sarana/prasarana

d. Untuk masyarakat miskin di kelurahan tidak 'tertinggal' diluncurkan program Takesra/Kukesra.

Ketika terjadi krisis ekonomi, jumlah penduduk miskin meningkat tajam karena merupakan gabungan dari penduduk miskin lama dan penduduk baru yang bersifat sementara (transient poverty). Untuk mengatasi masalah ini, dikeluarkan program Jaring Pengaman Sosial (JPS), yang dibagi dalam empat kelompok program, yaitu JPS Departemen teknis, JPS prioritas, JPS sektor-sektor pembangunan dan JPS monitoring. Krisis ekonomi yang menumbangkan Orde Baru kemudian diganti oleh Orde Reformasi yang di masa awal masih harus 
menghadapi sejumlah masalah terkait stabilitas, disintegrasi, dan dinamika politik.

Di masa reformasi ini Indonesia mulai menghadapi globalisasi dengan segala dampaknya, termasuk pengaruh asing yang kuat dalam ekonomi nasional. Salah satu isu krusial di masa ini adalah desentralisasi fiskal dalam kerangka otonomi yang diharapkan mampu mengatasi sejumlah masalah di daerah. Otonomi yang diharapkan mampu mengatasi sejumlah kelemahan pemerintah pusat ternyata belum sepenuhnya berhasil mengingat yang terjadi justru adalah maraknya korupsi di berbagai pelosok daerah. Kuatnya globalisasi dan kekuatan asing dalam perekonomian juga ikut menambah masalah kemiskinan selama era reformasi karena dicabutnya subsidi terhadap bahan bakar yang merupakan komponen utama dalam proses produksi dan konsumsi masyarakat. Akibatnya, berbagai masalah kemiskinan selalu muncul setiap kali isu kenaikan harga bahan bakar dihembuskan.

Sejumlah program yang selama ini disusun untuk mengatasi kemiskinan dinilai memiliki kekurangan. Kekurangan pada programprogram tersebut antara lain adalah:

a. Tidak ada jenjang program lanjutan sehingga kelompok yang sukses dalam tahapan pertama susah mengembangkan usaha selanjutnya

b. Terhambatnya laju pertumbuhan karena sistem pertanggungjawaban yang saling mengikat

c. Timing pencairan kredit yang tidak tepat

d. Kurangnya integrasi dan koordinasi program antar instansi

b. Mengatasi Kemiskinan di Indonesia dengan At-Turāts wa At-Tajdìd Hassan Hanafi

Sebagaimana dimaksudkan di awal makalah ini, at-turāts wa at-tajdìd Hassan Hanafi akan dicoba untuk dioperasionalkan dalam menjawab permasalahan kemiskinan di Indonesia. Berbekal penafsiran dalam Marāh Labid dan kondisi objektif di Indonesia saat ini, maka sejumlah pemikiran dapat dikontribusikan untuk mengatasi masalah kemiskinan di Indonesia. Kemiskinan selalu dilihat sebagai masalah nasional sehingga memberikan 
porsi besar kepada pemerintah untuk bertanggungjawab mengatasinya. Hal ini kemudian memunculkan sejumlah kebijakan pengentasan kemiskinan yang didanai dari pajak. Dengan demikian, pemerintah merupakan agen yang secara aktif mengumpulkan dana dari masyarakat yang mampu untuk kemudian disalurkan kepada masyarakat miskin.

Pola pemerintah mengumpulkan dana dan menyalurkannya secara konseptual memiliki relevansi dengan penyaluran zakat yang telah disinggung dalam kajian sebelumnya. Zakat yang diambil dari kelompok masyarakat yang memiliki kelebihan harta kemudian disalurkan kepada kelompok masyarakat yang membutuhkan diantaranya penduduk miskin. Faktor pembeda antara apa yang dilakukan pemerintah dengan zakat yang disebutkan dalam pembahasan adalah dimensi vertikal-ilahiah dalam zakat yang tidak ada dalam pajak. Selain itu, peruntukkan pajak juga beragam dan tidak terbatas pada membantu kelompok masyarakat miskin sebagaimana dipahami dari zakat.

Faktor terpenting dari kontribusi khazanah klasik Islam Indonesia untuk pengentasan kemiskinan sebenarnya berada dalam konsep harta dan peruntukkannya bagi seorang individu. Dalam penjelasan terdahulu nampak bahwa harta bagi seorang muslim adalah titipan untuk didistribusikan secara proporsional tidak hanya untuk kepentingan pribadi tetapi juga untuk kepentingan sosial. Hal berimbas kesadaran pada diri individu yang lebih sejahtera hidupnya untuk memberi kepada yang membutuhkan baik yang kelihatan karena meminta langsung maupun yang tidak kelihatan karena menjaga diri. Tidak hanya memberi, seorang yang kaya juga tidak menggunakan hartanya dengan maksud sombong tetapi tidak bermanfaat. Hal ini penting dilakukan karena seringkali masalah sosial muncul bukan karena kemiskinan saja, melainkan karena perilaku orang kaya yang cenderung pamer.

Kondisi semacam ini jika diturunkan dalam konteks Indonesia menandakan perlunya penyadaran akan fungsi harta bagi individu secara lebih komprehensif. Harta yang hanya dimaknai sebagai hasil kerja cenderung akan menimbulkan sifat pamer yang justru meningkatkan kecemburuan sosial di masyarakat. Untukitu, pemerintah dapat mengambil posisi untuk secara aktif mempromosikan sikap hidup sederhana sekaligus 
memberikan insentif ke arah tersebut. Bentuk insentif dapat bersifat negatif dalam artian pembatasan pemilikan aset atau kekayaan tertentu dapat diatur agar tidak terjadi monopoli penguasaan harta.

Pemerintah juga dapat mempromosikan kepedulian sosial sebagai bagian dari kebijakan untuk dunia usaha. Jika selama ini tanggung jawab sosial perusahaan semata diwujudkan dalam bantuan kemitraan yang mensyaratkan kemampuan dasar pada masyarakat binaan, maka kini dapat ditingkatkan dengan pemberdayaan yang benar-benar berangkat dari nol. Hal ini merupakan pengejawantahan dari pengakuan akan adanya hak masyarakat miskin dalam harta orang kaya.

\section{E. Penutup}

Pembahasan di atas menunjukkan bahwa pemikiran Hassan Hanafi tentang at-turāts wa at-tajdìd dapat diupayakan untuk diterapkan di Indonesia dalam rangka mengatasi kemiskinan sebagai problem sosial yang kronis. Upaya yang diusulkan adalah dengan meningkatkan partisipasi individu dan swasta dalam hal ini dunia usaha untuk lebih aktif membantu dan meningkatkan kualitas kehidupan masyarakat yang kekurangan. Aktifnya individu dan swasta dalam pengentasan kemiskinan merupakan aspek penting yang akan membantu program pemerintah dalam mengatasi kemiskinan. Ulasan ini juga menganjurkan peranan pemerintah untuk mendorong individu dan swasta untuk membantu masyarakat miskin. Insentif dapat diberikan kepada perusahaan atau individu yang secara aktif terlibat dalam program pengentasan kemiskinan.

Mengoperasionalkan pemikiran Hassan Hanafi tentang at-turāts wa attajdid terbukti dapat diwujudkan meskipun memiliki banyak tantangan. Sebagaimana dijelaskan sebelumnya sebuah khazanah klasik Islam sebenarnya memiliki kelebihan yang jika digali akan mampu membangkitkan kesadaran kolektif umat. Namun seiring berjalannya waktu, khazanah tersebut seringkali seolah terlupa atau kalah dibandingkan khazanah Barat yang ternyata jika diterapkan dalam konteks lokal tidak selalu berhasil. Oleh karenanya menggali khazanah klasik menjadi sebuah keniscayaan sebagai pembanding, sekaligus pendamping khazanah barat modern yang telah digunakan. 
Kajian ini memiliki sejumlah kelemahan terutama pada keterbatasan cakupan pembahasan karena hanya menggunakan satu tafsir. Padahal kajian tafsir dalam konteks Indonesia masih terbuka luas. Namun demikian, sebagai kajian awal, apa yang dimunculkan dalam makalah ini dapat terus dikembangkan dan dijadikan model dalam menggali khazanah klasik demi memperbaiki kehidupan umat agar mampu sejajar atau setidaknya mengejar ketertinggalan dari peradaban Barat.

\section{DAFTAR PUSTAKA}

Al-Bantanī, Nawawī. Marāh Labìd li Kasyf Ma'nā al-Qur'ān al-Majīd, t.k., AthThaba'ah Al-`Utsmaniyah, $1305 \mathrm{H}$.

Al-Hafidz, Ahsin W. Kamus Ilmu Alquran, Cetakan Kedua. Jakarta: Amzah, 2006.

Arsyad, Mustamin. “Signifikansi Tafsir Marāh Labīd terhadap Perkembangan Studi Tafsir di Nusantara", Jurnal Studi al-Qur'ān, Vol. 1 (3) 2006, hal. 615-636.

InpasOnline.com, "KritikTerhadap Metodologi Tafsir Al-Qur'an HasanHanafi”, 30 September 2010, Artikel website diakses dari http://inpasonline. com/new/kritik-terhadap-metodologi-tafsir-al-quran-hasan-hanafi/ 1 Maret 2011.

Khalil, M.S. Kunci (untuk Mencari Ayat) Al-Quran. Surabaya: Bina Ilmu, 1990. Musfah, Jejen. Indeks Al-Quran Praktis, Cetakan II. Jakarta: Hikmah, 2007.

Nadlir, Muhammad Abu "Legasi dan Pembaharuan Hasan Hanafi", 20 Oktober 2010, Artikel website diakses dari http:// abuenadlir.blogspot. com/2010/10/legasi-dan-pembaharuan-hasan-hanafi.html 1 Maret 2011.

Rahman, Afzalur. Al Qur'an Sumber Ilmu Pengetahuan, diterjemahkan oleh M. Arifin dari Quranic Scince. Jakarta: Bina Aksara, 1989.

Sholeh, Ahmad Khudori. Pemikiran Islam Kontemporer, Hasan Hanafi:Hermeneutika Humanistik. Yogyakarta: Jendela. 2003.

Taufiq Hidayat, Rachmat. Khazanah Istilah Al-Quran. Bandung: Mizan, 1989. Wikipedia, "Hassan Hanafi", Artikel website diakses dari http://en.wikipedia. org/wiki/Hassan_Hanafi pada 1 Maret 2011.

Zaini, Syahminan. Isi Pokok Ajaran Al-Qur'an. Jakarta: Kalam Mulia, 1986. 